\title{
A CONTRIBUtion TO THE LIFE HISTORY OF EUPHORBIA COROLLATA. ${ }^{x}$
}

\author{
Florence May Lyon. \\ (WITH PLATES XXII-XXIV) \\ INFLORESCENCE.
}

THE inflorescence of Euphorbia corollata is of the complicated form known as a cymose umbel. From the axils of bracts on the main stem of the inflorescence there arise three to five branches, each terminating in a smaller inflorescence called a cyathium, still occasionally referred to as "a flower" 2 (figs. I2, $\left.I_{3}, 14\right)$.

These branches in turn produce bracts with axillary branches and terminal cyathia, and so on through four, five, or rarely six generations of branches ( $f i g$. I4). As the secondary and tertiary branches of the inflorescence develop, there is a tendency to diminish the lateral members, so that the ultimate branching may become dichasial. Again, all the terminal cyathia on the branches preceding the penultimate may be lacking.

\section{THE CYATHIUM.}

The cyathium has every external appearance of a perfect, complete flower (fig. I2). The involucre of five white bracts looks like a gamopetalous perianth. At the entrance to the tubular portion are developed five glands, which, together with five delicate outgrowths of the involucre, nearly block the passage. Within this involucre and opposite its component bracts are five groups of staminate flowers. A group commonly consists of three members, and each staminate flower is a single stamen terminal on a pedicel, and distinguishable exter-

${ }^{x}$ Contributions from Hull Botanical Laboratory. X.

${ }^{2}$ Baillon: Histoire des plantes 5 : 109. 1874 . 
nally from a stamen only by a slight joint which marks the insertion of filament upon pedicel. In the center of the inflorescence arises the pistillate flower, distinguished also from a pistil by a joint in its axis. It is made up of three carpels forming a trilocular ovary with a single suspended anatropous ovule in each chamber, and a style with three deeply bifid branches. Masses of glandular hairs envelop the base of the pistillate flower, forming a dense screen between it and the staminate flowers. After fertilization the pedicel of the pistillate flower grows with great rapidity, carrying it far out of the involucre (fig. I2).

\section{ORGANOGENY.}

The first trace of the cyathium is a papilla-like outgrowth between two bracts which are themselves in the axil of a larger bract ( $f g ., I$, and the bud shown in fig. 12 ). Near the base of this papilla there soon appear five protuberances ( fig. 2), the forerunners of the involucre. In their axils arise the oldest staminate flowers $\left(\right.$ fig. $\left.3 s^{\mathrm{x}}\right)$. Simultaneously with these, and shortly before the appearance of the carpels, the three ovules are distinguishable on the outer rim of the papilla $(f i g .30)$. The three carpels develop independently from the main axis above the oldest staminate flowers, which, at the same time, give off near their bases branches which are the second generation of staminate flowers $(f i g .4)$. The carpels grow rapidly, their adjacent edges coalescing and turning inward as they develop, in such a way as to enclose each of the three ovules in a separate compartment (fig. 7). A third set of staminate branches spring from the pedicels of the second, and occasionally a fourth from these ( $f g$. 5). The notch marking the boundary between filament and pedicel appears when the stamen is nearly mature $\left(f i g \cdot 5 \mathrm{~s}^{\mathrm{I}}\right)$.

A regular perfect flower does not develop thus. Stamens arise acropetally from the flower axis, and not as branches from stamens of a preceding generation, as is evident here from the course of the bundles. The resemblance of a single cyathium to a reduced inflorescence of exactly the same type as 
the whole cluster ( fig. I4) is very marked, as may be seen by comparing the fibro-vascular bundles in the dichasial group of staminate flowers in fig. 5 , with the diagram of the main inflorescence in fig. 14 . If in the latter, the terminal flowers after the first be suppressed, and the second, third, and fourth branches produce but one branch each, the resulting arrangement would be strictly comparable to that which obtains in the cyathium of E. corollata. The tendency of the terminal flower of the cyathium (i.e., the pistillate) to disappear is marked, about one in ten having either a very rudimentary flower as in fig. ${ }_{5}$, or no trace of one at all. The cyathium of E. corollata may be interpreted then as a much reduced inflorescence, made up of certain ultimate branches of a more complex inflorescence, possibly of simple flowers, which is still undergoing reduction.

\section{MEGASPORANGIUM AND MEGASPORES.}

The very young ovule stands nearly erect in the lower part of the loculus $(\mathrm{fg} .6)$. It develops in such a manner as to become recurved, the loculus becoming more roomy by an intercalary growth of the base of the carpel and the funiculus. The stalk of the ovule, too, becomes elongated, until finally the ovule is suspended and anatropous, with the micropyle close to the funiculus and the raphe running along the inner edge ( figs. $6-I I)$. The development of the two integuments may be traced by the figures; the inner one appears first on the outer surface of the ovule, and is closely followed by the second, which soon surpasses it (figs. 7-II).

The embryo sac develops by the usual stages. A single hypodermal cell is differentiated from its neighbors and cuts off a primary wall cell (tapetum) (figs. I $8-20$ ). This is followed by a division of the primary sporogenous cell into an axial row of four mother cells, the lowermost of which develops into the sac (figs. 2I-24). The cells of the nucellus, and possibly of the epidermis near the upper end of the sac, divide with great rapidity, producing a long, slender neck and leaving the sac deeply situated (figs. 22, 23, 25, 26). 
A mass of active, glandular hairs develops on the placenta above the funiculus. Some of these apply themselves to the inner face of the nucellar neck, which bends toward them as it continues to lengthen (figs. II, 26,52). By the time the embryo sac is in the eight-celled stage, the tip of the neck has reached the narrow apex of the loculus and is closely appressed to the placental tissue $(f i g .52)$. The integuments envelop it, and the outer one becomes attached to the placental tissue in such a manner as to enclose the neck completely. An axial row of cells, larger and of looser structure than the surrounding tissue, is developed through the entire length of the neck (figs. 26, 52). These connect with a line of glandular cells that leads through the placental tissue to the stigmatic surface of the style (fig. 52). The pollen tube thus has a definite and direct passage to the modified cells in the neck, which break down as it approaches.

The extremely long synergids hang from the upper end of the sac with the oosphere suspended between their free tips (figs. 27-29) in the direct path of the pollen tube which passes between them $(f g .30)$. The fusion of the polar nuclei takes place near the egg in either the lcngitudinal or the tranverse axis of the sac (figs. 27, 28). The antipodals are very ephemeral, having been seen but once in several hundred slides. The endosperm nucleus does not divide before the egg is fertilized (fig. 30 end. n.). Immediately after the entrance of the pollen tube, the neck of the nucellus and the glandular hairs disappear, and the outer integument closes the mouth of the micropyle with a little cap that develops from its inner edge. At the time of fertilization, when the embryo sac has encroached on the nucellus to the base of the ovule, the tissue in this region divides into a mass of small but comparatively thick-walled cells, forming a floor upon which the sac rests (fig. II).

\section{MICROSPORANGIUM.}

When the stamen is but a small swelling $\left(f i g .3 s^{\mathrm{x}}\right)$ there appear in four distinct regions, approximately equidistant from 
one another, plates of hypodermal archesporial cells (figs. 30 , $31,32)$. All of these divide once to form axial rows ( $f g .32)$. These rows are radially placed, forming a mass of cells shaped like a truncated cone with its apex inward. Of the cells forming the inner layer, only a limited number, and, as a general thing, but one becomes the ancestor of the spore mother cells (fig. 33). The outer layer divides at once into two layers, thrusting the primary potential sporogenous cells down where there is even less room to divide ( $f g .33)$. Among these one cell soon may be distinguished by superior size and different stain as the forerunner of the spore mother cells referred to above. The hypodermal layer of cells divides by periclinal walls into two layers $(\mathrm{fg} .34)$. The tapetum is developed from the wall, and is frequently differentiated some time before the mother-cell stage ( fig. 34). The development of the spore mother cells $\left(f i g \cdot 3^{6}\right)$ and a clearly defined synapsis stage ( fig. 37 ), with the usual division into tetrads, follow (figs. $38-40$ ), In one preparation the mother celis had divided into fives and sixes instead of tetrads (figs. 42-46.) Nothing was observed to suggest how they were formed. It may be noted from the figures, however, that unlike the cases of Hemerocallis described by Juel, 3 the spores are of the same size.

The ordinary sequence of events leads to the development of the pollen grain, which is a spherical body with three deep grooves running from pole to pole. A large vegetative and a smaller lenticular generative nucleus were seen in the pollen grain and in the tube, but no trace of a division of the generative cell preceding tube formation (figs. 48-5I). The pollen tube, with one generative cell and the vegetative nucleus, were frequently seen in cross sections of the peculiar nucellar neck, which led to the inference that either the generative cell may not divide at all, or if it does, one of the male cells disappears before the pollen tube enters the micropyle. The actual fusion of the gametes was not observed.

${ }^{3}$ Cytologische Studien aus dem Bonner Botanischen Institut. 51-7.2. 1897 . 
SUMMARY,

The "flower" of Euphorbia corollata is an inflorescence of the same type as the general inflorescence or cluster of which it is a unit. This is shown not only by the rudimentary development of perianths about the "pistil" and "stamens," but more emphatically by the fact that the order in which the organs develop is not that of a flower, but of an inflorescence.

2. This inflorescence, or cyathium, shows a marked tendency to become reduced still further by the disappearance of its carpellate flower in the approximate ratio of one to ten.

3. The development of the ovule is marked by an elaborate outgrowth of the nucellus into a long neck whose direction of growth is guided by placental hairs which exert an attractive influence, causing it to bend toward them and in this way making a complete connection between the stigmatic cells and the embryo sac for the passage of the pollen tube.

4. Ovules appear before there is any trace of carpel, being clearly of cauline origin.

5. The synergids are remarkably long, and the antipodals so ephemeral that only once were they discovered in several hundred preparations. This suggests the possibility of their having been overlooked in certain instances where they have been reported as absent.

6. As a rule but a single cell becomes the ancestor of all the spore mother cells in a single pollen sac.

7. The tapetum may be clearly differentiated, at least one division preceding the pollen mother cells. It is developed from the wall.

8. Abnormal cases of five and six spores instead of tetrads were observed.

9. The synapsis stage was found with perfect regularity.

I0. Evidence was obtained suggesting that the generative cell may not divide.

The University of Chicago. 


\section{EXPLANATION OF PLATES.}

\section{PLATE XXII.}

The figures, with the exception of figs. 15, 16, 17, are diagrams. In all others, unless otherwise indicated, the optical combination was Reichert ocular 4 and Bausch and Lomb $\frac{1}{12}$ oil immersion. The drawings have been reduced to three-eighths of their original size as drawn with the Zeiss camera.

FIG. I. Young bud of a cyathium of E. corollata with no differentiation of flowers.

FIG. 2. Same older, showing developing involucre $(I)$ in axils of bracts (b). Vascular bundles in this and succeeding figures indicated by dotted lines.

FIG. 3. Still more advanced stage, in which five staminate flowers $\left(s^{\mathrm{r}}\right)$ have developed in the axils of the involucral leaves; the free margin of the papilla is slightly elevated into three orules. Two cyathia of a younger generation are shown in the axils of the bracts $(b)$.

FIG. 4. Ovules more advanced $(o)$. Carpels have appeared at the bases of the ovules $(c)$. A second group of staminate flowers, each of which is a branch from the staminate flower just above it $\left(s^{*}\right)$. Involucre enclosing all flowers.

FIG. 5. Carpels about to unite with axis of flower. A mature staminate flower $\left(s^{x}\right)$ with a notch marking the insertion of the filament upon the pedicel. Staminate flowers of the second, third, and fourth generations showing the dichasial arrangement. The gland $(g)$ and ingrowing flap are developing on the inner margin of the involucre, while the five free petallike parts are turning outward. In this, as in the preceding figures, $b$ indicates the two green leaves which envelop the cyathium.

Figs. 6-io show the shifting position of the ovule from nearly erect to an anatropous suspended position. The two integuments are shown in each figure, the inner appearing the earlier.

FIG. II. The nearly mature ovule with the nucellar neck bent toward the glandular hairs on the placenta. The shape of the embryo sac and the pad of thick walled small cells at the base of the nucellus are shown diagrammatically.

FIG. I 2. Habit sketch of a cyathium after fertilization of ovules. A younger cyathium is developing in the axil of one of the green bracts that enveloped the older cyathium during its growth.

FIG. 13. Ground plan of cyathium.

FIG. I4. Diagram of main inflorescence, a cymose umbel.

FIG. I 5. Portion of an abnormal cyathium in which no pistillate flower has developed. 
Figs. 16, I7. Abnormal staminate flowers; one with accessory anthers developed at the notch $(f g . I 6)$, the other with a cup-like perianth in the same situation ( $f i g .17)$.

\section{PLATE XXIII.}

Figs. I 8-20. Young megasporangia, showing first division of primary archesporial cell into tapetal and primary sporogenous cells, In fig. I9 the primary tapetal has in turn divided, as has also the adjacent epidermal cell.

FIG. 2I. Next stage in mother cell row.

Figs. 22-24. One-celled embryo sac with remnant of mother cell row above and marked development of nucellar tissue in this region.

FIG. 25. Two-celled embryo sac; nucellus dividing further, and epidermis forming two layers of cells.

FIG. 26. Four-celled embryo sac; several glandular hairs with their conspicuous nuclei applying themselves to "neck;" differentiation of axial row of cells into so-called "channel cells ;" portions of the two integuments shown in outline.

FIG. 27. Eight-celled embryo sac; the elongated synergids with the egg between their free tips lie in the upper part of the narrow sac; the polar nuclei fusing; the ephemeral antipodals.

FIG. 28. Polar nuclei fusing in transverse axis.

FIG. 29. The upper end of the sac in the eight-celled stage showing the relative positions of the synergids, the egg, and the endosperm nucleus to the "channel."

FIG. 30. Fertilization stage; pollen tube with male gamete passing between the disintegrating synergids toward egg lying beneath; the endosperm nucleus has not divided.

\section{PLATE XXIV.}

FIG. 30a. Young microsporangium showing one cell of archesporial plate differentiated.

FIG. 3I. More advanced stage.

FIG. 32. Microsporangium showing two of the four plates of archesporial cells; one undergoing division.

FIG. 33. Still later stage, where the hypodermal layer seen at the right of $f g .32$ has divided, thrusting the layer under it down toward the center of the anther; only one cell in each of the conelike masses gives evidence of becoming the ancestor of the spore mother cells.

FIG. 34. A stage in which the tapetum is differentiated; about twelve sporogenous cells, ten of which show in the section.

FIG. 35. Later stage; tapetum not yet differentiated. 
FIG. 36. Spore mother cell stage; tapetum developed.

FIG. 37. Synapsis stage.

FIG. 38. Stages following synapsis.

FIG. 39. Division into tetrads.

FIGS. 40, 4I. Formation of microspores.

Figs. 42-46. Irregular division into five and six spores instead of tetrads.

Figs. 47-50. Development of pollen grains and division of nucleus into a larger vegetative and a smaller lenticular generative nucleus.

FIG. 52. Diagram of pistil showing relation of stigmatic surface, path of pollen through placenta, and connection with channel in neck of nucellus leading to embryo sac. 


\section{$2 \mathrm{BHL}$ Biodiversity Heritage Library}

Lyon, Florence May. 1898. "A Contribution to the Life History of Euphorbia corollata." Botanical gazette 25(6), 418-426. https://doi.org/10.1086/327701.

View This Item Online: $\underline{\text { https://www.biodiversitylibrary.org/item/94870 }}$

DOI: https://doi.org/10.1086/327701

Permalink: https://www.biodiversitylibrary.org/partpdf/222885

\section{Holding Institution}

Missouri Botanical Garden, Peter H. Raven Library

\section{Sponsored by}

Missouri Botanical Garden

\section{Copyright \& Reuse}

Copyright Status: Public domain. The BHL considers that this work is no longer under copyright protection.

This document was created from content at the Biodiversity Heritage Library, the world's largest open access digital library for biodiversity literature and archives. Visit BHL at https://www.biodiversitylibrary.org. 